\title{
PRINSIP ITIKAD BAIK BERDASARKAN PASAL 251 KUHD DALAM ASURANSI KERUGIAN
}

\author{
Oleh: \\ Eti Purwiyantiningsih \\ Fakultas Hukum Universitas Jenderal Soedirman Purwokerto
}

\begin{abstract}
Everybody has their own risk with their life or their own. The best way to avoid the risk is by sending the risk to another party which has capable to hande it, throught insurance agreement. This insurance has many purposes such has taken over the risk to others. In insurance the participant has obligation regulation in 251 KUHD in which determined that all of the statement both true or false or all of the condition has known by participant as a reflection of honesty by participant, it can will not an agreement based on the same qualification it there is know by participant the agreement will be canceled. In the indemnity insurance as 251 KUHD there is no fully application because there is still touty at the good faith, it means that the agreement will cancel because of no good faith from the participant, therefore it will be canceled
\end{abstract}

Kata kunci : itikad baik dan asuransi kerugian.

\section{A. Pendahuluan}

Tiap orang yang memiliki suatu benda tentu menghadapi suatu risiko bahwa nilai dari benda miliknya itu akan berkurang baik karena hilangnya benda itu, maupun karena kerusakan atau karena musnah terbakar atau karena sebab lainnya. Banyak diantara sebab-sebab yang menjadi pengurangan nilai benda itu dapat di cegah dan sudah dapat diperkirakan terjadinya, tetapi banyak hal juga sebab-sebab yang mengurangi nilai benda itu mempunyai sifat yang tidak dapat diduga sebelumnya dan tidak diharapkan terjadinya.

Soeisno Djojosoedarso dalam Disertasi Arief Soeryono mengatakan bahwa risiko timbul karena adanya ketidakpastian, yang berarti ketidakpastian adalah merupakan kondisi yang menyebabkan keragu-raguan seseorang mengenai kemampuannya untuk meramalkan kemungkinan terhadap hasil-hasil yang akan terjadi di masa mendatang. Kondisi yang tidak pasti itu karena berbagai sebab, antara lain:

1. Tenggang waktu antara perencanaan suatu kegiatan sampai kegiatan itu berakhir/ menghasilkan dimana makin panjang tenggang waktu makin besar ketidakpastiannya.

2. Keterbatasan informasi yang tersedia yang diperlukan dalam penyusunan rencana.
3. Keterbatasan pengetahuan/kemampuan/ teknik pengambilan keputusan dari perencanaan. $^{1}$

Menurut Purwosutjipto, resiko adalah kewajiban menanggung atau memikul kerugian sebagai akibat dari suatu peristiwa di luar kesalahannya, yang menimpa benda yang menjadi miliknya. ${ }^{2}$ Untuk mengatasi resiko, salah satu metode yang paling tepat adalah dengan cara mengalihkannya kepada pihak lain yaitu melalui asuransi atau pertanggungan, karena tujuan asuransi adalah mengalihkan risiko yang ditimbulkan oleh peristiwa yang tidak dapat diharapkan terjadinya kepada pihak lain yang mengambil risiko itu untuk mengganti kerugian. Pasal 246 Kitab Undang-Undang Hukum Dagang (KUHD) menentukan bahwa asuransi atau pertanggungan adalah suatu perjanjian dengan mana seorang penanggung mengikatkan dirinya kepada seorang tertanggung, dengan menerima premi, untuk memberikan penggantian kepadanya karena suatu kerugian atau kehilangan, kerusakan atau kehilangan

\footnotetext{
Arief Suryono, 2003, Tanggung Jawab Penanggung dalam Asuransi Kesehatan di Indonesia, Surabaya: Disertasi Program Pascasarjana Universitas Airlangga, hlm. 34 35.

2 Purwosutjipto, 1983, Pengertian Pokok Hukum Dagang Indonesia, Jilid 6, Hukum Pertanggungan, Jakarta: Djambatan, hlm. 24.
} 
242 Jurnal Dinamika Hukum

Vol. 8 No. 3 September 2008

keuntungan yang diharapkan yang mungkin akan dideritanya karena peristiwa tidak tentu.

Berdasarkan Pasal 246 KUHD kita dapat menarik unsur-unsur penting dalam asuransi atau pertanggungan, yaitu:

1. Pihak-pihak, yaitu penanggung dan tertanggung.

2. Status pihak-pihak. Penanggung harus berstatus sebagai perusahaan berbadan hukum dapat berbentu Perseroan Terbatas (PT), Perusahaan Perseroan Koperasi. Tertanggung dapat berstatus sebagai perseorangan, persekutuan atau badan hukum.

3. Obyek asuransi, dapat berupa benda, hak atau kepentingan yang melekat pada benda, dan sejumlah uang yang disebut premi atau ganti kerugian.

4. Peristiwa asuransi, yaitu perbuatan hukum (Legal Act) berupa persetujuan atau kesepakatan antara penanggung dan tertanggung mengenai obyek asuransi peristiwa tidak pasti (evenemen) yang mengancam benda asurasi, dan syarat-syarat yang berlaku dalam asuransi.

5. Hubungan asuransi, adalah keterikatan (Legality bound) yang timbul karena kesepakatan bebas. ${ }^{3}$

Sebagai suatu perjanjian, supaya sah asuransi atau pertanggungan itu haruslah memenuhi semua syarat-syarat sahnya perjanjian yang diatur dalam Pasal 1320 Kitab UndangUndang Hukum Perdata (KUH Perdata), yaitu adanya 4 (empat) syarat :

1. Sepakat mereka yang mengikatkan diri;

2. Kecakapan untuk membuat suatu perikatan;

3. Suatu hal tertentu;

4. Suatu sebab yang halal;

Untuk sahnya perjanjian pertanggungan disamping harus memenuhi Pasal $1320 \mathrm{KUH}$ Perdata juga harus memenuhi ketentuan Pasal 251 KUHD yang mengharuskan adanya pemberitaan tentang semua keadaan yang diketahui oleh tertanggung mengenai benda pertanggungan. ${ }^{4}$

\footnotetext{
3 Abdulkadir Muhammad, 2002. Hukum Asuransi Indonesia, Bandung: PT. Citra Aditya Bakti, hlm. 8-9.

4 Purwosutjipto, Op Cit, hlm. 33
}

Pasal 251 KUHD menentukan bahwa semua pemberitaan yang salah atau tidak benar atau penyembunyian keadaan-keadaan yang diketahui oleh si tertanggung, betapapun jujurnya itu terjadi pada pihaknya yang bersifat sedemikian rupa sehingga perjanjian tidak akan diadakan atau diadakan dengan syarat-syarat yang sama bilamana penanggung mengetahui keadaan yang sesungguhnya dari benda itu, menyebabkan pertanggungan itu batal.

Dalam asuransi, khususnya asuransi kerugian ada 4 (empat) prinsip asuransi, yaitu :

1. Prinsip kepentingan yang dapat diasuransikan (Insurable interest);

2. Prinsip jaminan atas kerugian (Indemnity);

3. Prinsip kepercayaan (Trustfull);

4. Prinsip itikad baik (Utmost Goodfaith) ${ }^{5}$.

Prinsip itikad baik ini berhubungan dengan Pasal 1320, 1321, 1323, 1328 dan 1338 KUH Perdata serta Pasal 251 KUHD. Yang di maksud dengan itikad baik dalam Pasal 1338 ayat (3) KUH Perdata adalah bahwa perjanjian harus dilaksanakan secara pantas dan patut. ${ }^{6}$ Itikad baik bukan saja harus ada pada saat pelaksanaan perjanjian, tetapi juga pada saat dibuatnya atau ditandatanganinya suatu perjanjian. ${ }^{7}$ Agar prinsip itikad baik ini benarbenar terpenuhi sangat diharapkan kepada pihak tertanggung untuk tidak menyalahgunakan kepercayaan yang telah diberikan oleh pihak penanggung. Pihak penanggung juga harus bertikad baik dengan menjelaskan luas jaminan yang diberikan dan hak-hak dari tertanggung.

Kepercayaan dari pihak penanggung harus diimbangi dengan itikad baik dari tertanggung, yaitu dengan memberikan keterangan dan data yang diketahuinya atas interest yang akan ditutup asuransinya. Itikad baik ini bukan hanya ada pihak tertanggung tetapi juga harus ada pada pihak penanggung, karena yang lebih mengetahui mengenai luas jaminan dan hak-

\footnotetext{
5 Radiks Purba, 1992, Memahami Asuransi di Indonesia, Jakarta: PT. Raja Grafindo Persada, hlm. 44.

6 J. Satrio, 2001, Hukum Perikatan, Perikatan yang Lahir dari Perjanjian Buku II, Bandung: PT. Citra Aditya Bakti, hlm. 177.

7 Suharnoko, 2004, Hukum Perjanjian Teori dan Analisa Kasus, Jakarta: Prenada Media, hlm. 4-5.
} 
hak tertanggung adalah penanggung. Oleh karena itu ketika asuransi ditutup, penanggung juga harus menjelaskan luas jaminan dan hakhak tertanggung. ${ }^{8}$

Pasal 251 KUHD merupakan ketentuan khusus dari Pasal 1321 dan 1322 KUH Perdata. Kekhususannya adalah bahwa Pasal 251 KUHD tidak mempertimbangkan apakah perbuatan tertanggung itu dilakukan dengan sengaja atau tidak sengaja. Prinsipnya, seandainya penanggung mengetahui keadaan yang sebenarnya dari benda yang diasuransikan itu, dia tidak akan mengadakan asuransi dengan syarat-syarat yang demikian itu. ${ }^{9}$

Di dalam asuransi atau pertanggungan, yang perlu untuk batalnya pertanggungan adalah bahwa penanggung tidak akan mengadakan pertanggungan atau tidak akan mengadakannya dengan syarat yang sama, seandainya ia mengetahui keadaan-keadaan itu.

Tujuan Pasal 251 KUHD adalah untuk melindungi penanggung atau membebaskannya dari risiko yang secara tidak adil diperalihkan kepadanya, sehingga dalam Pasal 251 KUHD itu tidak menjadi pertimbangan apakah pada tertanggung terdapat itikad baik atau tidak. Dengan demikian, penyembunyian atau mendiamkan suatu keadaan tentang benda pertanggungan itu tidaklah dipersoalkan apakah itu terjadi dengan disengaja oleh si tertanggung ataukah karena ia tidak mengetahui keadaan itu atau karena menganggap keadaan itu tidak penting. Tidak perlu apakah tertanggung sudah mengetahui sebelumnya seperti yang disyaratkan dalam Hukum Perdata mengenai kekeliruan. ${ }^{10}$

Walaupun tujuan Pasal 251 KUHD itu untuk melindungi penanggung, tetapi banyak sarjana yang mengemukakan keberatan-keberatan terhadap ketentuan pasal tersebut. Menurut Emmy Pangaribuan Simanjuntak keberatan ini memang tepat, sebab mengetahui sebelumnya keadaan yang dikemukakan oleh

\footnotetext{
Radiks Purba, Op Cit, hlm. 32.

Abdulkadir Muhammad, Op Cit, hal 73.

10 Emmy Pangaribuan Simanjuntak, 1982, Hukum Pertanggungan (Pokok-pokok Pertanggungan Kerugian Kebakaran dan Jlwa), Yogyakarta: Seksi Hukum Dagang Fakultas Hukum Unversitas Gajah Mada, hlm. 47.
}

tertanggung, maka ia oleh Pasal 251 KUHD tidak diberi kesempatan menyelamatkan pertanggungan itu. Adalah masuk akal bilamana Pasal 251 KUHD itu di dalam praktik dikesampingkan oleh pihak-pihak yang bersangkutan. ${ }^{11}$

Berdasarkan uraian di atas, maka tulisan ini dimaksudkan untuk menjelaskan mengenai penerapan prinsip itikad baik berdasarkan Pasal 251 KUHD dalam asuransi kerugian.

\section{B. Pembahasan}

Asuransi kerugian berlaku setelah Surat Permintaan Penutupan Asuransi (SPPA) yang diserahkan tertanggung kepada penanggung disetujui oleh penanggung. Dengan disetujuinnya SPPA, berarti bertemulah kehendak dari tertanggung dan penanggung dengan kata lain terjadilah persesuaian kehendak antara tertanggung dan penanggung. Dengan demikian perjanjian asuransi kerugian bersifat konsensuil, lahir berdasarkan kesepakatan tanpa memerlukan syarat formalitas tertentu, karena perjanjian asuransi kerugian sudah berlaku sebelum polisnya dibuat. Polis baru dibuat kemudian berdasarkan SPPA.

Pasal 255 KUHD menentukan bahwa pertanggungan harus diadakan secara tertulis dengan sepucuk akta, yang dinamakan polis. Apabila melihat ketentuan pasal tersebut, polis merupakan syarat sahnya perjanjian asuransi, padahal polis adalah alat bukti tentang adanya perjanjian asuransi, karena perjanjian asuransi bersifat konsensuil.

Pasal 257 ayat (1) KUHD menentukan bahwa perjanjian pertanggungan ada segera setelah diadakan, hak-hak dan kewajibankewajiban timbal balik dari tertanggung dan penanggung mulai sejak saat itu, bahkan sebelum polis ditandatangi.

Pasal 257 KUHD menyatakan bahwa perjanjian pertanggungan itu bersifat konsensuil, akan tetapi Pasal 255 KUHD mengharuskan pembuatan perjanjian pertanggungan itu dalam suatu akta yang disebut polis. Polis merupakan tanda bukti adanya perjanjian pertanggungan bukan merupakan unsur dari perjanjian per-

\footnotetext{
${ }^{11} \mathrm{Ibid}, \mathrm{hlm} .48-49$.
} 
244 Jurnal Dinamika Hukum

Vol. 8 No. 3 September 2008

tanggungan, dengan tidak adanya polis tidak menyebabkan perjanjian pertanggungan batal ${ }^{12}$

Sifat konsensuil dari perjanjian asuransi dapat dilihat pula dari ketentuan Pasal 246 KUHD dari kalimat “.........seorang penanggung mengikatkan diri kepada seorang tertanggung.......". berdasarkan kalimat tersebut dapat disimpulkan bahwa penanggung berdasarkan persesuaian kehendaknya sendiri mengadakan perjanjian pertanggungan dengan seorang tertanggung tanpa ada paksaan dari pihak lain atau salah satu pihak memaksakan kehendaknya kepada pihak lain.

Asas konsensualisme dapat disimpulkan dalam Pasal 1320 KUH Perdata. Dalam Pasal itu ditentukan bahwa perjanjian pada umumnya tidak diadakan secara formal, tetapi cukup dengan adanya kesepakatan kedua belah pihak. Kesepakatan merupakan persesuaian antara kehendak dan persyaratan yang dibuat oleh kedua belah pihak. $^{13}$ Kata konsensualisme berasal dari bahasa latin consensus yang berarti sepakat. Arti asas konsensualisme ialah pada dasarnya perjanjian dan perikatan yang timbul karenanya itu sudah dilahirkan sejak detik tercapainya kesepakatan. Dengan kata lain, perjanjian itu sudah sah apabila sudah sepakat mengenai hal-hal yang pokok dan tidaklah diperlukan suatu formalitas. ${ }^{14}$

Asas konsensualisme menentukan bahwa suatu perjanjian yang dibuat antara dua atau lebih orang telah mengikat sehingga telah melahirkan kewajiban bagi salah satu atau lebih pihak dalam perjanjian tersebut, segera setelah orang tersebut mencapai kesepakatan atau konsensus, meskipun kesepakatan telah dicapai secara lisan semata-mata. Ini berarti pada prinsipnya perjanjian yang mengikat dan berlaku sebagai perikatan bagi para pihak yang berjanji tidak memerlukan formalitas. Walaupun demikian, untuk menjaga kepentingan pihak debitor (atau yang berkewajiban untuk memenuhi prestasi) tertentu, maka diadakan-

\footnotetext{
${ }^{12}$ Purwosutjipto, Op Cit, hlm. 62.

${ }^{13}$ Salim H.S. 2003, Hukum Kontrak Teori \& Teknik Penyusunan Kontrak, Jakarta: Sinar Grafika, hlm. 10.

${ }^{14}$ Budiman N.P.D. Sinaga, 2005, Hukum Kontrak \& Penyelesaian Sengketa dari Perspektif Sekretaris, Jakarta: PT. Raja Grafindo Persada, hlm. 12-13.
}

lah bentuk-bentuk formalitas atau dipersyaratkan adanya tindakan nyata tertentu. ${ }^{15}$

Persesuaian kehendak antara para pihak saja belum menimbulkan perjanjian, karena hukum hanya mengatur perbuatan nyata dari manusia. Kehendak manusia adalah sesuatu hal yang abstrak, sehingga untuk dapat diketahui dan bertemu dengan kehendak pihak lain, maka kehendak tersebut harus dinyatakan. Kehendak yang dinyatakan tersebut harus nyata dan dapat dimengerti oleh pihak lain. Apabila kehendak yang dinyatakan tersebut sampai dan dapat dimengerti pihak lain dan pihak lain tersebut menyatakan menerimanya, maka timbullah sepakat. ${ }^{16}$

Persesuaian kehendak atau pernyataan kehendak dapat dinyatakan dengan lisan, tulisan/surat, dan lain-lain. Pihak yang satu menawarkan atau memajukan "usul" (proposal), serta pihak yang lain menerima atau menyetujui usul tersebut. Jadi dalam persetujuan terjadi acceptance/penerimaan atau persetujuan usul, lahirlah "persetujuan" atau "kontrak" yang "mengakibatkan ikatan hukum" bagi para pihak. ${ }^{17}$

Persesuaian kehendak dalam asuransi kerugian dinyatakan secara tertulis, yaitu dengan diajukannya permohonan dengan mengisi SPPA oleh tertanggung kepada penanggung yang kemudian disetujui oleh pennggung. $\mathrm{Di}$ dalam SPPA tersebut termuat data lengkap dari tertanggung, keterangan lengkap mengenai benda pertanggungan, dan syarat-syarat pertanggungan. Disetujuinya SPPA tertanggung oleh penanggung, berarti telah terjadi pernyataan persesuaian kehendak dari kedua belah pihak secara tertulis, yang berarti diterimanya tawaran/usul/proposal tertanggung melalui SPPA oleh penanggung, dan lahirlah perjanjian asuransi.

\footnotetext{
${ }^{15}$ Gunawan Widjaja, 2005, Seri Hukum Bisnis Memahami Prinsip Keterbukaan (Aanvullend Recht) dalam Hukum Perdata, Jakarta: PT. Raja Grafindo Persada, hlm. 248249.

16 J. Satrio, 1995, Hukum Perikatan, Perikatan yang Lahir Karena Perjanjian, Buku I, Bandung: PT. Citra Aditya Bakti, hlm. 165.

${ }^{17}$ M. Yahya Harahap, 1986, Segi-segi Hukum Perjanjian, Bandung: Alumni, hlm. 23-24.
} 
Di dalam asuransi kerugian, penanggung dan tertanggung sepakat mengadakan perjanjian asuransi. Kesepakatan itu ditandai dengan persetujuan penanggung atas SPPA yang di ajukan oleh tertanggung. Perjanjian pertanggungan kerugian dibuat secara tertulis dalam suatu polis yang diterbitkan berdasarkan SPPA, dimana dalam polis sudah disebutkan dengan lengkap mengenai obyek pertanggungan. Hak dan kewajiban tertanggung dan penanggung di atur di dalam polis.

Identitas lengkap dari tertanggung tercantum di dalam polis. Berdasarkan data tersebut, bisa perorangan ataupun badan usaha (korporasi) dapat diketahui bahwa tertanggung adalah cakap/wenang melakukan tindakan hukum. Hal ini didasarkan pada fakta bahwa seseorang yang mengajukan permohonan penutupan perjanjian asuransi atas obyek yang menjadi miliknya atau tanggung jawab hukum terhadap pihak ketiga adalah orang yang cakap menurut hukum, karena sudah dewasa, tidak berada di bawah pengampuan.

Pihak penanggung dalam asuransi kerugian adalah suatu perusahaan berbadan hukum. Direktur perusahaan yang menandatangani polis adalah pihak yang sah mewakili perusahaan berdasarkan Anggaran Dasar Perusahaan. Berdasarkan fakta tersebut, berarti tertanggung dan penanggung adalah pihakpihak yang wenang melakukan tindakan hukum baik secara subyektif maupun obyektif. Kewenangan subyektif artinya kedua pihak sudah dewasa, sehat ingatan, tidak berada di bawah perwalian (trusteeship), atau pemegang kuasa yang sah. Kewenangan obyektif artinya tertanggung adalah pihak yang sah mewakili Perusahaan Asuransi berdasarkan Anggaran Dasar Perusahaan. ${ }^{18}$

Yang menjadi obyek dalam asuransi kerugian adalah harta kekayaan. Obyek asuransi tersebut harus jelas dan pasti. Apabila berupa harta kekayaan, harta kekayaan apa berapa jumlahnya dan ukurannya, dimana letaknya,

\footnotetext{
${ }^{18}$ Abdulkadir Muhammad, Op Cit, hal 50-51.
}

apa mereknya, buatan mana, berapa nilainya dan sebagainya. ${ }^{19}$

Prestasi dari suatu perjanjian harus tertentu atau dapat ditentukan. Hal ini obyek yang diperjanjikan spesifikasinya harus detail dan konkrit. Suatu obyek perikatan harus dapat ditentukan juga obyeknya diperkenankan dan prestasinya dimungkinkan. ${ }^{20}$

Perjanjian asuransi pada dasarnya adalah perjanjian penggantian kerugian. Tujuan asuransi adalah memperalihkan risiko tertanggung kepada penanggung. Dengan adanya perjanjian asuransi ini penanggung mempunyai kewajiban mengganti kerugian tertanggung dengan imbalan pembayaran premi dari tertanggung. Semuanya tertuang di dalam polis.

Dengan melihat polis asuransi kerugian dapat diketahui bahwa apa yang diperjanjikan antara tertanggung dengan penanggung tidak dilarang oleh undang-undang, tidak bertentangan dengan ketertiban umum dan kesusilaan. Isi dari perjanjian tersebut adalah apa yang menjadi tujuan dari tertaggung dan penanggung, yaitu adanya peralihan risiko dari tertanggung kepada penanggung, yang memberikan konsekuensi pembayaran ganti rugi dari penanggung apabila tertanggung menderita kerugian sebagai akibat dari peristiwa yang dijamin dalam polis, dan kewajiban membayar premi bagi tertanggung.

Pembentuk undang-undang tidak memberikan perumusan yang jelas mengenai "sebab yang halal" di dalam KUH Perdata. Sebab adalah sesuatu yang menyebabkan orang membuat perjanjian, tetapi yang dimaksud dengan sebab yang halal dalam Pasal $1320 \mathrm{KUH}$ Perdata bukanlah sebab dalam arti yang menyebabkan atau mendorong orang membuat perjanjian, melainkan sebab dalam arti "isi perjanjian sendiri” yang menggambarkan tujuan yang akan dicapai para pihak. ${ }^{21}$

Berdasarkan hal tersebut, mengenai "sebab yang halal" berkaitan dengan asas kebebas-

\footnotetext{
19 Ibid, hlm. 51

${ }^{20}$ Ade Maman Suherman, 2005, Aspek Hukum dalam Ekonomi Global, Edisi Revisi, Bogor: Ghalia Indonesia, hlm. 23.

${ }^{21}$ Abdulkadir Muhammad, 1990, Hukum Perikatan, Bandung: PT. Citra Aditya Bakti, hlm. 94.
} 
246 Jurnal Dinamika Hukum

Vol. 8 No. 3 September 2008

an berkontrak. Zaeni Asyhadie mengatakan bahwa kebebasan berkontrak artinya para pihak bebas membuat kontrak dan menentukan sendiri isi kontrak tersebut sepanjang tidak bertentangan dengan undang-undang, ketertiban umum dan kesusilaan dan didasari atas itikad baik. Dengan demikian, asas ini mengandung makna bahwa kedua belah pihak bebas dalam menentukan isi perjanjian, asalkan tidak bertentangan dengan ketertiban umum, kesusilaan dan peraturan perundangan. ${ }^{22}$

Untuk sahnya perjanjian pertanggungan disamping harus memenuhi Pasal $1320 \mathrm{KUH}$ Perdata juga harus memenuhi ketentuan Pasal 251 KUHD yang menentukan bahwa semua pemberitaan yang salah atau tidak benar atau penyembunyian keadaan-keadaan yang di ketahui oleh si tertanggung, betapapun jujurnya itu terjadi pada pihaknya yang bersifat sedemikian rupa sehingga perjanjian tidak akan diadakan atau diadakan dengan syarat-syarat yang sama bilamana penanggung mengetahui keadaan yang sesungguhnya dari benda itu, menyebabkan pertanggungan itu batal.

Kewajiban pemberitaan dari tertanggung dalam asuransi kerugian sudah dimulai sejak mengajukan SPPA. Tertanggung harus menyebutkan dengan jelas dan rinci mengenai benda pertanggungan. Apa yang diisi oleh tertanggung dalam SPPA akan menjadi pertimbangan diterima atau tidaknya permohonan tersebut oleh penanggung.

Kewajiban pemberitaan dari tertanggung dalam asuransi kerugian diatur dalam polis, yang isinya Tertanggung wajib mengungkapkan fakta material yaitu informasi, keterangan, keadaan dan fakta yang mempengaruhi pertimbangan penanggung dalam menerima atau menolak suatu permohonan penutupan asuransi dan dalam menetapkan suku premi apabila permohonan dimaksud diterima. Selain itu tertanggung wajib membuat pernyataan yang benar tentang hal-hal yang berkaitan dengan penutupan asuransi, yang disampaikan baik

\footnotetext{
${ }^{22}$ Zaeni Asyhadie, 2005, Hukum Bisnis, Prinsip dan Pelaksanaannya di Indonesia, Jakarta: PT. Raja Grafindo Persada, hlm. 29.
}

pada waktu pembuatan perjanjian asuransi maupun selama jangka waktu pertanggungan.

Disisi lain jika tertanggung tidak melaksanakan kewajiban sebagaimana diatur di atas, penanggung tidak wajib membayar kerugian yang terjadi dan berhak menghentikan pertanggungan serta tidak wajib mengembalikan premi. Ketentuan tersebut tidak berlaku dalam hal fakta material yang tidak diungkapkan atau yang dinyatakan dengan tidak benar itu telah diketahui oleh penanggung namun penanggung tidak mempergunakan haknya untuk menghentikan pertanggungan dalam waktu 30 (tiga puluh) hari setelah penanggung mengetahui pelanggaran tersebut.

Berdasarkan ketentuan tentang kewajian untuk mengungkapkan fakta dalam polis dapat diketahui bahwa dalam asuransi kerugian dituntut adanya itikad baik dari tertanggung dalam mengungkapkan fakta yang sebenarnya dari benda pertanggungan. Apabila tertanggung tidak memenuhi kewajibannya, penanggung tidak berkewajiban mengganti kerugian dan berhak menghentikan pertanggungan. Ketentuan dalam polis asuransi kerugian tersebut tidak seberat ketentuan dalam Pasal 251 KUHD yang tidak mempertimbangkan ada-tidaknya itikad baik dari tertanggung dalam mengungkapkan fakta tentang benda pertanggungan. Apabila diketahui adanya kekeliruan pemberitaan saja meskipun tertanggung sudah berbuat jujur, mempunyai itikad baik, pertanggungan tetap batal.

Ketentuan Pasal 251 KUHD terlalu memberatkan bagi tertanggung yang beritikad baik. Banyak sarjana yang mengemukakan keberatan terhadap ketentuan Pasal 251 KUHD, karena dapat menimbulkan ketidakadilan. Oleh karena itu di dalam praktik para pihak dapat mengesampingkan ketentuan Pasal 251 KUHD dengan klausula "Renuntiatie" dan klausula "sudah mengetahui".

Pada polis asuransi kerugian tidak terdapat klausula renuntiatie ataupun klausula sudah mengetahui. Namun demikian pada praktiknya tidak sepenuhnya menerapkan Pasal 251 KUHD yang berarti tetap memperhatikan adanya itikad baik dari tertanggung dalam 
mengungkapkan fakta tentang benda pertanggungan. Disamping ketentuan dalam polis tentang kewajiban mengungkapkan fakta tidak sekeras ketentuan Pasal 251 KUHD dan sanksi terhadap pelanggaran ketentuan tersebut oleh tertanggung tidak berlaku apabila penanggung mengetahui pelanggaran itu tetapi tidak menggunakan haknnya dimana ketentuan ini tidak terdapat dalam Pasal $251 \mathrm{KUHD}$, di dalam polis juga terdapat ketentuan tentang perubahan risiko. Tertanggung dibebani kewajiban untuk memberitahukan kepada penanggung setiap ada perubahan keadaan dari benda pertanggungan yang dapat memperbesar risiko. Ketentuan tersebut memperlihatkan bahwa di dalam polis asuransi kerugian dituntut adanya itikad baik dari tertanggung dalam mengungkapkan fakta tentang benda pertanggungan.

Hal ini dipertegas bahwa pada praktiknya penanggung tidak akan meneliti lebih jauh tentang keadaan benda pertanggungan, karena penanggung percaya bahwa tertanggung telah beritikad baik dalam menyampaikan semua fakta tentang benda pertanggungan. Apalagi dengan ketentuan tentang perubahan risiko dalam polis, menyebabkan tertanggung tidak mempunyai alasan untuk tidak menyampaikan tentang keadaan yang sebenarnya dari benda pertanggungan.

Dengan adanya kepercayaan dari pihak penanggung yang diimbangi dengan itikad baik dari tertanggung, menunjukkan adanya penerapan prinsip kepercayaan dan prinsip itikad baik dalam asuransi kerugian. Itikad baik tidak saja ada pada tertanggung, tetapi juga ada pada pihak penanggung karena penanggung sudah menjelaskan luas jaminan yang diberikan kepada tertanggung, yang semuanya tertuang di dalam polis. Pasal 1338 yat (3) KUH Perdata menentukan bahwa setiap perjanjian harus dilaksanakan dengan itikad baik. Yang di maksud dengan itikad baik dalam Pasal 1338 ayat (3) KUH Perdata adalah bahwa perjanjian harus dilaksanakan secara pantas dan patut. ${ }^{23}$

\footnotetext{
23 J. Satrio, 2001, Hukum Perikatan, Perikatan yang Lahir Karena Perjanjian, Buku II, Bandung: PT. Citra Aditya Bakt, hlm, 177.
}

Dengan adanya itikad dari tertanggung dalam mengungkapkan fakta tentang benda pertanggungan dan itikad baik dari penanggung tentang luas jaminan yang diberikan kepada tertanggung yang tertuang di dalam polis, berarti perjanjian pertanggungan sudah di laksanakan secara pantas dan patut. Ukuran kepantasan dan kepatutan disini tentunya bukan hanya menggunakan ukuran kepatutan dan kepantasan bagi tertanggung dan penanggung sendiri, tetapi pengungkapan kebenaran fakta dari benda pertanggungan yang diimbangi dengan jaminan yang diberikan penanggung adalah kepantasan dan kepatutan yang bersifat obyektif. Perilaku tertanggung dan penanggung dalam melaksanakan perjanjian asuransi tersebut sudah sepantasnya dan sepatutnya menurut ukuran umum dalam masyarakat, ukuran yang obyektif.

Itikad baik dalam pelaksanaan kontrak mengacu kepada itikad baik yang obyektif. Standar yang digunakan dalam itikad baik obyektif adalah standar yang obyektif yang mengacu pada suatu norma yang obyektif. Perilaku para pihak dalam kontrak harus diuji atas dasar norma-norma obyektif yang tidak tertulis yang berkembang dalam masyarakat. Ketentuan itikad baik menunjuk kepada normanorma tidak tertulis yang sudah menjadi norma hukum sebagai suatu sumber hukum tersendiri. Norma tersebut dikatakan obyektif karena tingkah laku tidak didasarkan pada anggapan para pihak sendiri, tetapi tingkah laku tersebut harus sesuai dengan anggapan umum tentang itikad baik tersebut. ${ }^{24}$

Apabila melihat dalam praktik asuransi kerugian, bahwa kewajiban mengungkapkan fakta yang sebenarnya tentang benda pertanggungan sudah dimulai sejak penutupan perjanjian yaitu dalam pengisian SPPA, maka itikad baik dalam asuransi kerugian tidak hanya ada pada pelaksanaan perjanjian saja, tetapi dalam penutupan perjanjian sudah ada itikad baik. Hal ini sejalan dengan pendapat Suharnoko yang mengatakan bahwa itikad baik

\footnotetext{
${ }^{24}$ Ridwan Khaerandy, 2004, Itikad Baik dalam Kebebasan Berkontrak, Jakarta: Program Pascasarjana Fakultas Hukum Universitas Indonesia, hlm. 195.
} 
248 Jurnal Dinamika Hukum

Vol. 8 No. 3 September 2008

bukan saja harus ada pada saat pelaksanaan perjanjian tetapi juga pada saat dibuatnya atau ditandatanganinya perjanjian. ${ }^{25}$

\section{Penutup}

Ketentuan Pasal 251 KUHD tidak diterapkan sepenuhnya dalam asuransi kerugian, karena dalam asuransi kerugian masih diperhatikan adanya itikad baik dari tertanggung. Kewajiban pemberitaan tentang keadaan dari benda pertanggungan dalam asuransi kerugian menuntut adanya itikad baik dari tertanggung, artinya pertanggungan tidak berjalan seandainya kesalahan pemberitaan itu terjadi karena ada itikad tidak baik dari tertanggung, sedangkan menurut Pasal 251 KUHD tidak dipertimbangkan ada atau tidak adanya itikad baik dari tertanggung dalam mengungkapkan fakta tentang benda pertanggungan. Apabila ada kekeliruan pemberitaan saja, meskipun tertanggung sudah berbuat jujur, pertanggungan tetap batal.

\section{Daftar Pustaka}

Asyhadie, Zaeni. 2005. Hukum Bisnis Prinsip dan Pelaksanannya di Indonesia. Jakarta: PT. Raja Grafindo Persada;

Harahap, M. Yahya. 1986. Segi-Segi Hukum Perjanjian. Bandung: Alumni;

Khaerandy, Ridwan. 2004. Iktikad Baik dalam Kebebasan Berkontrak. Jakarta: Program Pascasarjana Fakultas Hukum Universitas Indonesaia;

Muhammad, Abdulkadir. 1990. Hukum Perikatan. Bandung: PT. Citra Aditya Bakti;

Muhammad, Abdulkadir, 2002, Hukum Asuransi Indonesia, PT. Citra Aditya Bakti, Bandung.

Purba, Radiks. 1992. Memahami Asuransi di Indonesia. Jakarta: PT. Raja Grafindo Persada;

Purwosutjipto. 1983. Pengertian Pokok Hukum Dagang Indonesia, Jilid 6 Hukum Pertanggungan. Jakarta: Djambatan;

Salim H.S. 2003. Hukum Kontrak Teori dan Teknik Penyusunan Kontrak. Jakarta: Sinar Grafika;
Satrio, J. 1995. Hukum Perikatan, Perikatan yang Lahir Karena Perjanjian Buku I. Bandung: PT. Citra Aditya Bakti;

2001. Hukum Perikatan, Perikatan yang Lahir Karena Perjanjian Buku II. Bandung: PT. Citra Aditya Bakti;

Simanjuntak, Emmy Pangaribuan. 1982. Hukum Pertanggungan, Pokok-Pokok Pertanggungan Kerugian, Kebakaran dan Jiwa. Yogyakarta: Seksi Hukum Dagang Fakultas Hukum Universitas Gajah Mada;

Sinaga, Budiman N.P.D. 2005. Hukum Kontrak dan Penyelesaian Sengketa dari Perspektif Sekretaris. Jakarta: PT. Raja Grafindo Persada;

Suharnoko. 2004. Hukum Perjanjian Teori dan Analisa Kasus. Jakarta: Prenada Media;

Suherman, Ade Maman. 2005. Aspek Hukum dalam Ekonomi Global. Edisi Revisi, Bogor: Ghalia Indonesia;

Suryono, Arief. 2003. Tanggung Jawab Penanggung dalam Asuransi Kesehatan di Indonesia. Surabaya: Disertasi Program Pascasarjana Universitas Airlangga;

Widjaja, Gunawan. 2005. Seri Hukum Bisnis Memahami Prinsip Keterbukaan (Aanvullend Recht) dalam Hukum Perdata. Jakarta: PT. Raja Grafindo Persada,

\footnotetext{
${ }^{25}$ Suharnoko, Op Cit.
} 